\title{
Citra politik Susilo Bambang Yudhoyono dan Joko Widodo di media sosial
}

\author{
Theresia Intan Putri Hartiana ${ }^{1}$, Agatha Winda Setyarinata ${ }^{2}$, Yuli Nugraheni ${ }^{3}$ \\ ${ }^{1,2,3}$ Universitas Katolik Widya Mandala Surabaya, Surabaya, Indonesia
}

\begin{abstract}
ABSTRAK
Penelitian ini mengenai penerimaan masyarakat mengenai citra Jokowi dan SBY dalam meme Hambalang. Satir ini muncul di berbagai media sosial, salah satunya Twitter sejak 18 Maret 2018 dikarenakan peristiwa kunjungan Presiden Joko Widodo dan Tour De Java Susilo Bambang Yudhoyono yang banyak diperbincangkan khalayak. Ada yang menyebut bahwa kedua peristiwa tersebut adalah gambaran rivalitas antara Presiden Joko Widodo dengan Susilo Bambang Yudhoyono. Media mulai membicarakan keberkaitan antara kedua peristiwa ini. Warganet juga mulai muncul dengan konten-konten satirnya guna membicarakan peristiwa ini, yaitu dengan mengkolase foto Tour De Java dan kunjungan ke Hambalang. Kendati sudah ada tanggapan dari Susilo Bambang Yudhoyono, konten-konten satir tentang peristiwa ini tetap viral. Penelitian ini bertujuan mendeskripsikan penerimaan tokoh politik mengenai meme Hambalang. Penelitian ini dilaksanakan secara kualitatif dengan melibatkan enam informan dikumpulkan dalam sebuah sesi Focus Group Discussion. FGD dilaksanakan menggunakan pertanyaan semi-terstruktur sebagai cara pengumpulan data. Metode penelitian dilakukan dengan analisis resepsi audiens. Hasil penelitian dipaparkan bahwa informan satir tersebut menunjukkan sebagai cerminan realita bahwa disejajarkannya foto SBY dan Jokowi dalam meme sebagai bentuk rivalitas keduanya. Di sisi lain, kemunculan satir tersebut dimaknai sebagai humor dalam ranah internet, dan juga meme tersebut sebagai eksploitasi media sosial untuk kepentingan tersebut. Untuk penerimaan informan mengenai citra politik SBY Jokowi dalam meme Hambalang berada pada posisi contesting reading. Simpulan penelitian ini adalah ada pemaknaan yang beragam yang dimiliki oleh informan mengenai munculnya satir tentang Hambalang.
\end{abstract}

Kata-kata Kunci: Citra; politik; meme; internet; media sosial

\section{Susilo Bambang Yudhoyono and Jokowi political images in social media}

\begin{abstract}
This research focuses on public acceptance of the image of Jokowi and SBY in Hambalang memes. This satire appeared on various social media, one of which was twitter since March 18, 2018, due to the visit of President Joko Widodo and Susilo Bambang Yudhoyono's Tour De Java which was widely discussed by the public. Some say that the two events are a picture of rivalry between President Joko Widodo and Susilo Bambang Yudhoyono. The media began to discuss the relationship between these two events. Citizens also began to emerge with satirical content to discuss this event, namely by collecting photos of Tour De Java and a visit to Hambalang. Although there has been a response from Susilo Bambang Yudhoyono, satirical content about this event remains viral. This study aims to describe the acceptance of political figures regarding Hambalang memes. This research was conducted qualitatively by involving six informants gathered in a Focus Group Discussion session. FGD uses semi-structured questions as a way to collect data. The research method uses audience reception analysis. The results of the study explain that informants suggest satirical content shown a reflection of the reality that SBY and Jokowi's photos in memes as a form of rivalry. On the other hand, the appearance of the satirical content in a meme is interpreted as humor by internet users, especially in social media. The reception of informants regarding the political image of SBY-Jokowi in a meme of Hambalang was in the position of contesting reading. This research concludes that there are various meanings perceived by informants regarding the Hambalang meme.
\end{abstract}

Keywords: Image; political; memes; internet; social media

Korespondensi: Theresia Intan Putri Hartiana, S.Sos., M.I.Kom. Universitas Katolik Widya Mandala Surabaya. Jalan Dinoyo no. 42-44 Surabaya 60265, Email: theresiaintan2502@gmail.com 


\section{PENDAHULUAN}

Sidak ke Hambalang Sedetik Rusak Tour De Java Sebulan. Kalimat sindiran tersebut berkembang luas di dunia maya dengan menampilkan gambar Susilo Bambang Yudhoyono menangkupkan kedua tangan di depan mulut. Seolah memiliki keberkaitan, muncul gambar lain dan tulisan sindiran di internet dalam berbagai versi untuk mengambarkan kegiatan kunjungan Presiden Joko Widodo ke Wisma Atlet Hambalang. Pemantik dari sindiran ini terjadi saat Presiden Joko Widodo mencuit melalui akun Twitter pribadinya seperti tampak pada gambar 1 .

\section{Q1. Joko Widodo}

\section{Following}

Sedih melihat aset negara di proyek Hambalang mangkrak. Penuh alang-alang. Harus diselamatkan -Jkw

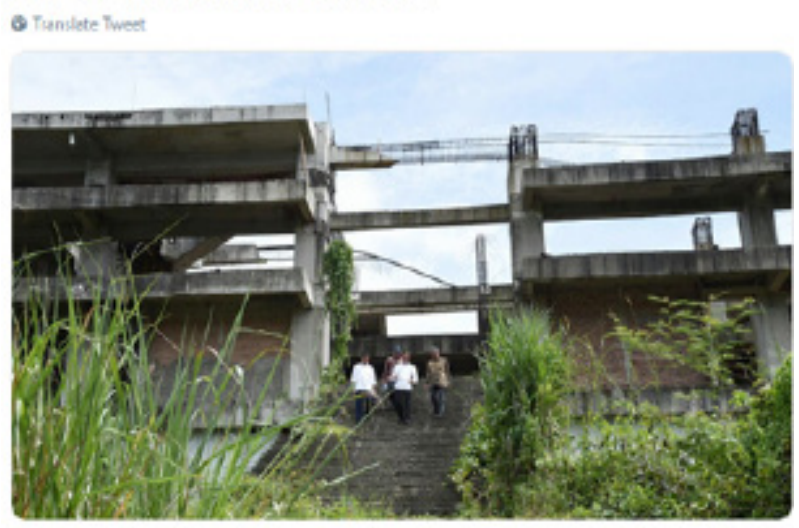

1:31 PM - 18 Mar 2016

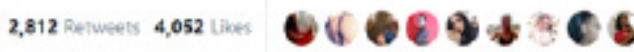

Sumber: Data penelitian, 2018

\section{Gambar 1 Cuitan Presiden Joko Widodo pada Media} Sosial Twitter
Sebelumnya Susilo Bambang Yudhoyono mengadakan kunjungan yang bertajuk Tour De Java. Tour De Java menjadi kegiatan Susilo Bambang Yudhoyono menyapa kader-kader partai Demokrat. Hambalang menjadi salah satu destinasi yang dihampiri.

Peristiwa kunjungan Presiden Joko Widodo dan Tour De Java tersebut kemudian banyak diperbincangkan khalayak. Ada yang menyebut bahwa kedua peristiwa tersebut adalah gambaran rivalitas antara Presiden Joko Widodo dengan Susilo Bambang Yudhoyono. Media mulai membicarakan keberkaitan antara kedua peristiwa ini. Warganet juga mulai muncul dengan konten-konten satirnya guna membicarakan peristiwa ini, yaitu dengan mengkolase foto Tour De Java dan kunjungan ke Hambalang. Kendati sudah ada tanggapan dari Susilo Bambang Yudhoyono, kontenkonten satir tentang peristiwa ini tetap viral.

Konten viral di internet merefleksikan peran baru media digital. Indonesia pernah menjadi negara yang memiliki pengguna Twitter terbanyak sedunia. Berkaitan dengan ini, Twitter menjadi sumber alternatif bagi warganet untuk memahami kondisi politik yang terjadi di Indonesia (Wibowo \& Mirawati, 2013). Secara teknis, karakteristik media sosial memungkinkan adanya interaktivitas antarpengguna. Perangkat digital yang mendukung penggunaan media sosial berimplikasi pada lanskap audiens hari ini. 
Pengguna internet kini bisa menjadi konsumen sekaligus produsen sebuah konten (Jenkins, 2004). Aspek inilah yang memunculkan audiens baru yang signifikan.

Konten viral yang dibahas dalam penelitian ini berupa satir politik. Satir politik dalam internet tidak hanya digunakan untuk tujuan politik saja. Menurut Yang \& Jiang, praktik satir politik dalam internet bisa menjadi bentuk ritual sekaligus resistensi. Menurut mereka, terkadang pengguna internet hanya bersamasama menertawakan kejadian politik yang ada bersama dengan kawan-kawan maupun keluarga inilah yang disebut dengan ritual dan ini merupakan tujuan yang nonpolitis (Yang \& Jiang, 2015). Namun menurut mereka pula, satir politik di internet juga bisa menjadi sebuah bentuk resistensi individu yang merupakan tujuan politis. Bentuk resistensi yang demikian memantik sebuah sinisme terhadap situasi politik tertentu. Satir politik yang memuat guyonan tentang Hambalang juga dapat dipahami sebagai bentuk ritual dimana pengguna internet bersama-sama menertawakan personifikasi antara Susilo Bambang Yudhoyono dan Presiden Joko Widodo. Namun, satir politik ini juga bisa menjadi sebuah bentuk resistensi dimana pengguna internet menolak mendapati kejadian korupsi serupa Hambalang terulang kembali.

Berkaitan dengan tujuan politis dari sebuah satir politik di internet, viralnya konten tersebut akan berkaitan dengan pembentukan citra politik dari Susilo Bambang Yudhoyono dan Presiden Joko Widodo. Firmansyah mengungkapkan bahwa citra politik adalah identitas politik. Citra merupakan visualisasi dari atribut yang diberikan dan dipersepsikan oleh pihak luar. Citra ini bisa berupa reputasi dan kredibilitas yang dipersepsikan oleh masyarakat (Firmansyah, 2008). Citra politik inilah yang merupakan hasil dari proses pembelajaran dan identifikasi dalam benak individu.

Citra Politik tidak hanya diciptakan oleh partai saja, namun dengan munculnya kontenkonten satir politik di internet akan mampu membentuk suatu "individualism connectivity" yang memungkinkan orang per orang akan terhubung dan menangkap proyeksi citra. Susilo Bambang Yudhoyono, sebagai ketua partai Demokrat dan juga mantan Presiden Indonesia serta Joko Widodo yang saat ini menjadi Presiden, dikonstruksikan pada sebuah realita yang dibentuk oleh pengguna internet dan mampu menciptakan persepsi di masyarakat lainnya. Citra merupakan hal yang personal, hal ini berarti bahwa citra adalah persepsi personal atas objek, sehingga citra dapat berbeda antara satu orang dengan yang lainnya. Citra tidak hanya sekedar refleksi atas organisasi, citra merupakan konstruksi dari masing-masing orang (Kotler \& Foz dalam Firmansyah, 2008). 
Salah satu publik yang turut mampu mempersepsi atas makna satir tentang Susilo Bambang Yudhoyono dan Joko Widodo adalah aktivis politik. Aktivis politik merupakan orang yang aktif untuk selalu mempersepsi pesan dan memproduksimakna(McQuail,2010). Audience merupakan khalayak aktif yang memberikan pemaknaan terhadap tayangan media yang disaksikan, sehingga mampu memberikan makna berbeda dari konstruksi realita yang diberikan media. Melalui pemaknaan ini peneliti ingin melihat pemaknaan politikus terkait citra politik Susilo Bambang Yudhoyono dan Joko Widodo dalam sebuah konten viral tentang Hambalang. Perbedaan sosiokultural tentunya akan menimbulkan pemaknaan yang berbeda terkait peristiwa Hambalang berikut citra yang ditangkap dari masing-masing tokoh. Sehingga penting untuk melihat bagaimana informan sebagai khalayak aktif memaknai satir tersebut.

\section{METODE PENELITIAN}

Penelitian ini dilaksanakan secara kualitatif dengan melibatkan enam informan. Informan dipilih secara purposif. Informan pertama bernama Erna S. Lahir tanggal 23 Desember 1973. Erna adalah perempuan etnis Jawa, bekerja sebagai konsultan, pendidikan terakhir adalah magister, secara aktif berpartisipasi dalam PDI Perjuangan sebagai kader.

Informan kedua adalah Yuska Harimurti.
Lahir tanggal 3 Oktober 1974. Yuska adalah laki-laki keturunan etnis Jawa dan Betawi, pendidikan terakhir adalah SMA, sedang bekerja sebagai pekerja sosial, aktif berpartisipasi dalam organisasi politik bernama Lintas Iman dan HAM. Informan ketiga bernama Robi Dharmawan. Robi lahir tanggal 15 Mei 1987. Robi adalah laki-laki keturunan etnis Tionghoa, menyelesaikan pendidikan sarjana, sedang bekerja sebagai seorang guru, tidak pernah berpartisipasi di organisasi politik.

Informan selanjutnya bernama Habsari Savitri. Habsari lahir tanggal 16 Juli 1975. Habsari adalah perempuan keturunan etnis Jawa, pendidikan terakhir adalah sarjana, sedang bekerja sebagai anggota DPRD Jawa Timur, secara aktif berpartisipasi dalam PDI Perjuangan sebagai kader. Lalu ada Eka Rahmawati yang lahir tanggal 9 September 1975. Eka adalah perempuan keturunan Jawa, sedang bekerja sebagai konsultan independen, pendidikan terakhir adalah magister, secara aktif berpartisipasi dalam Panwas Kabupaten/ Kota di wilayah Jawa Timur.

Terakhir, ada Heru Krisdianto. Heru lahir tanggal 22 April 1974. Heru adalah laki-laki keturunan etnis Jawa, sedang bekerja sebagai penulis, pendidikan terakhir adalah sarjana, mantan aktivis '98, secara aktif berpartisipasi di Partai Demokrat (sebagai kader) dan di IKOH (Ikatan Keluarga Orang Hilang) Jawa Timur. 


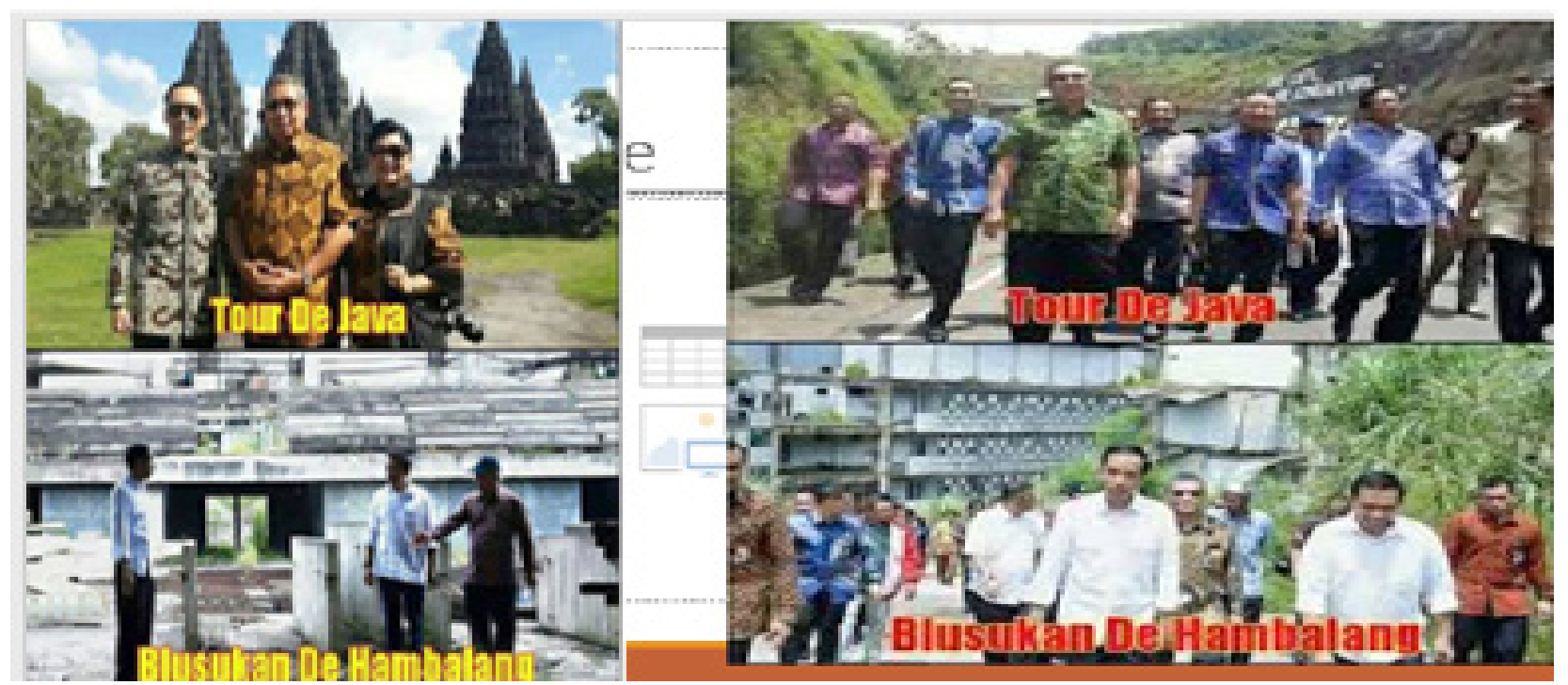

Sumber: Data penelitian, 2018

Gambar 2 Slide pertama yang ditayangkan di hadapan informan

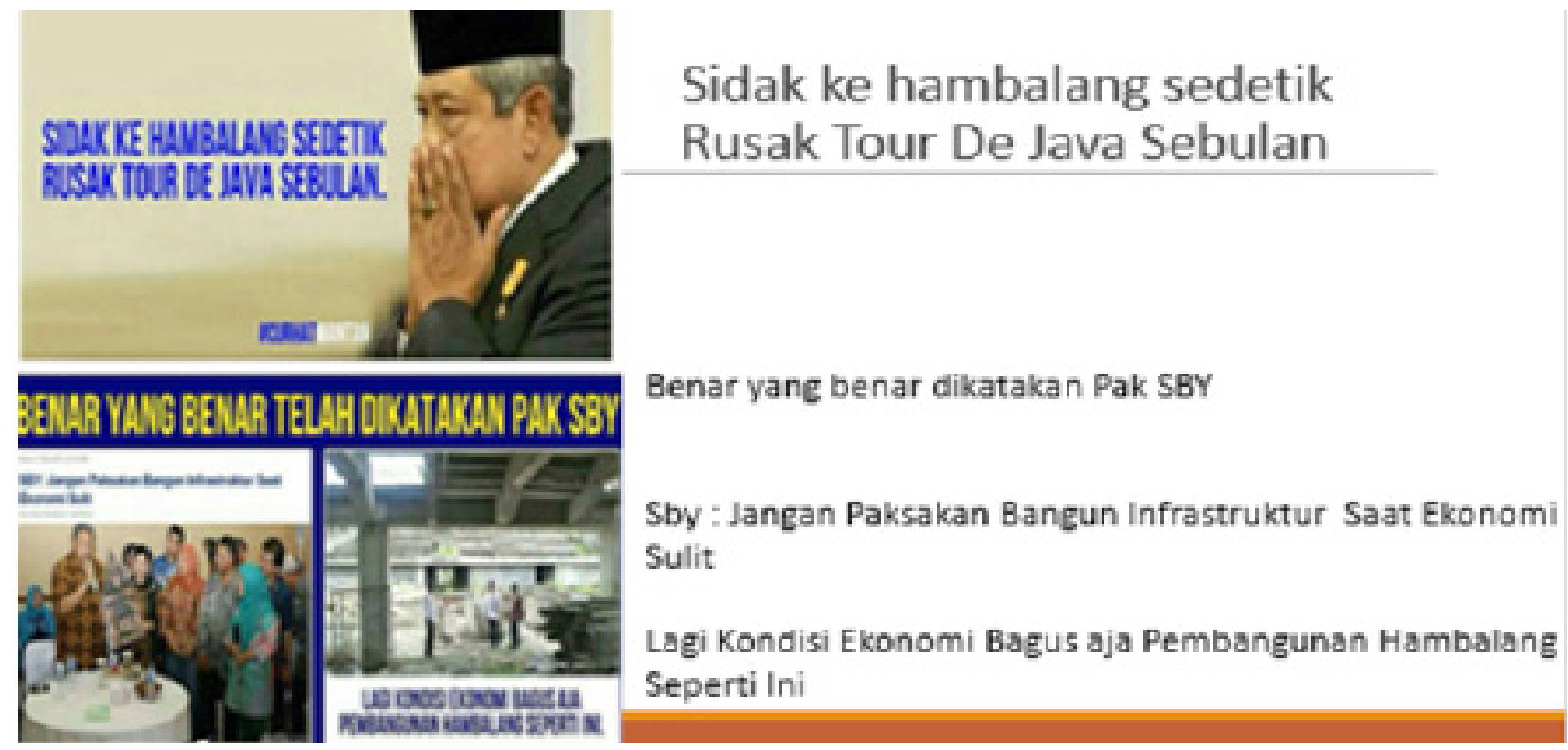

Sumber: Data penelitian, 2018

Gambar 3 Slide kedua yang ditayangkan di hadapan informan

Keenam responden dikumpulkan dalam informan. Sebelum FGD dimulai, moderator sebuah ruangan untuk sesi Focus Group menunjukan serangkaian gambar 2 dan 3.

Discussion (FGD). FGD dilaksanakan

Hasil FGD kemudian ditranskrip lalu menggunakan pertanyaan semi-terstruktur. dilakukan analisis dengan menggunakan Sebelum FGD dilangsungkan, peneliti telah metode analisis resepsi (Michelle, 2007). melakukan pra-riset untuk menentukan kualitas Resepsi audiens terhadap gambar viral yang 
ditayangkan dalam kedua slide tersebut akan dianalisis mulai dari tingkatan denotatif hingga tingkatan konotatif.

\section{HASIL DAN PEMBAHASAN}

Pada level pemaknaan denotatif, kegiatan Tour De Java dan kunjungan ke Hambalang diberitakan oleh media sebagai peristiwa memiliki agenda yang berbeda. Kendati demikian temuan dalam penelitian ini menunjukan bahwa gambar viral menawarkan sebuah logika tentang korelasi kedua peristiwa tersebut. Informan Habsari pertama kali menangkap logika tersebut. Menurutnya unsur perbandingan antara peristiwa kunjungan
Presiden Joko Widodo ke Hambalang dengan peristiwa Tour De Java oleh Susilo Bambang Yudhoyono. Informan Habsari mengatakan,

“Jomplang beda banget." Ia lanjut menjelaskan: "Yang satu kayanya kok lebih ke wisata, yang satu datang ke tempat yang kayaknya kalo dilihat rumput-rumputnya sudah tinggi kemudian tidak terawat, satunya yang di atas itu kayanya di Pacitan ya".

Informan Habsari menangkap makna denotatif dalam gambar kolase pada transparant mode. Menurutnya, demikianlah kebenaran peristiwa yang ada, yaitu ada korelasi antara kedua peristiwa.

Informan Yuska juga menangkap makna yang sejalan dengan informan Habsari, ia

Tabel 1 Model komposit multi-dimensi resepsi audiens

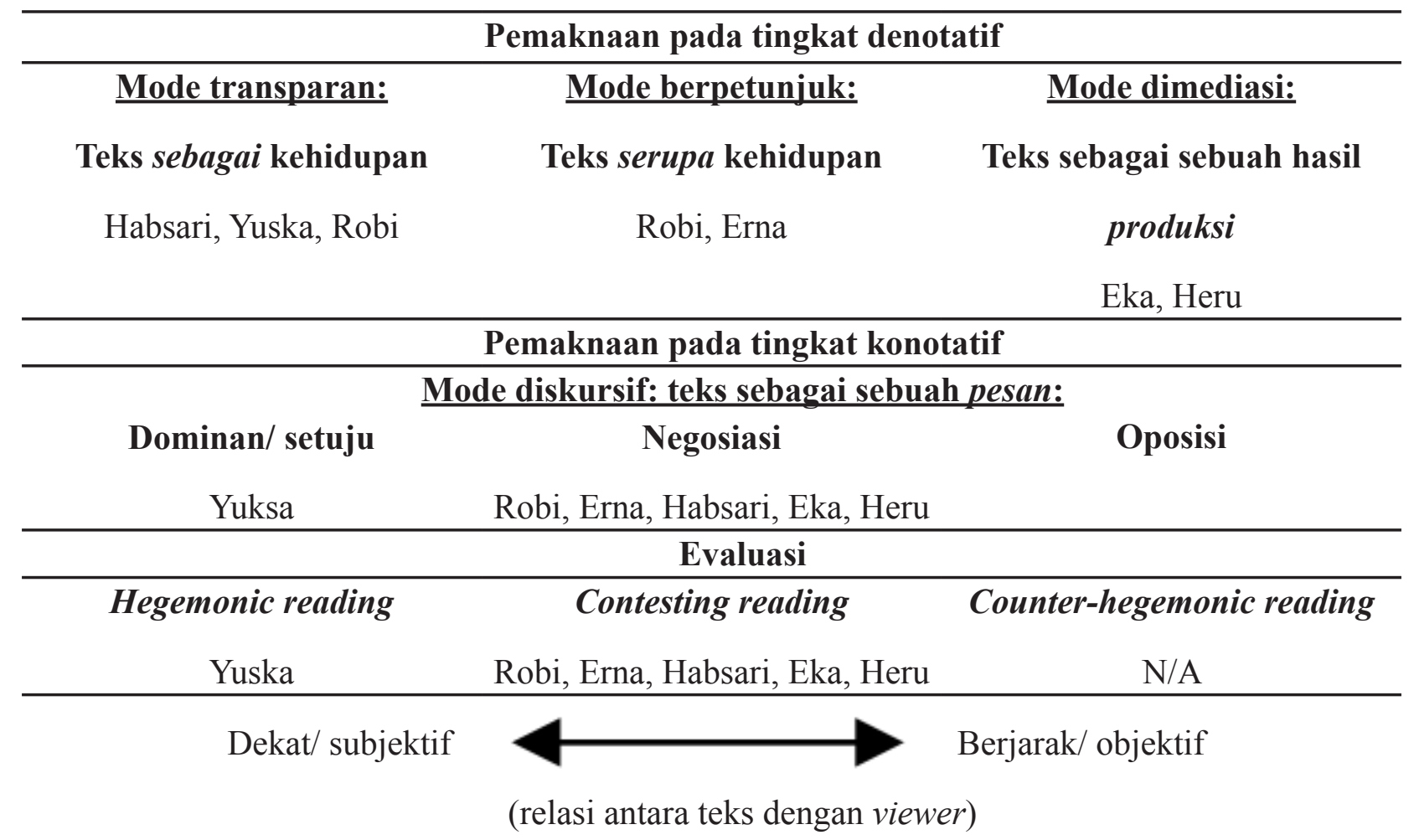

Sumber: Hasil penelitian, 2018 
menjelaskan:

"Tapi ini kan ada latar belakang juga, jadi sebelum ada ini, apa yang dilakukan oleh SBY waktu itu keliling Jawa sambil melakukan evaluasi terhadap kepemimpinan Jokowi dan saat SBY ngomong banyak evaluasi lima a, b, c, d, e, jadi counter evaluasi yang dilakukan SBY di counter oleh Jokowi dengan ini”.

Menurut informan Yuska, gambar viral ini menyajikan sebuah aksi saling sindir secara simbolis antara Presiden Joko Widodo dengan Susilo Bambang Yudhoyono. Pada tahap ini, informan Yuska menganggap bahwa gambar viral menyajikan kebenaran peristiwa.

Sejalan dengan informan Habsari dan informan Yuska, informan Robi juga berpendapat bahwa gambar viral menyajikan sebuah kebenaran, yaitu adanya sindiran yang ditujukan kepada Susilo Bambang Yudhoyono. Informan Robi berpendapat bahwa kedua peristiwa tersebut merupakan aksi dan reaksi. Kunjungan Presiden Joko Widodo ke Hambalang merupakan reaksi berupa sindiran terhadap Tour De Java yang dilakukan oleh Susilo Bambang Yudhoyono. Informan Robi berpendapat bahwa secara implisit "[gambar viral] lebih mengacu kepada attacking di SBY".

Argumen-argumen yang diajukan ketiga informan, yaitu Habsari, Yuska, dan Robi, merefleksikan kolase ini sebagai cerminan realita (text as life). Baik informan Habsari, informan Yuska, maupun informan Robi tidak mengkritisi bahwa ada kemungkinan fakta di lokasi peristiwa tersebut tidak sesuai dengan tafsir yang mereka miliki. Ketiganya menerima bahwa disejajarkannya foto Susilo Bambang Yudhoyono dan Presiden Joko Widodo merupakan bentuk rivalitas antara keduanya. Kemiripan lokasi, yaitu di Hambalang, ditafsir oleh ketiga informan sebagai upaya Presiden Joko Widodo mencatut kasus korupsi yang terjadi di masa pemerintahan Susilo Bambang Yudhoyono.

Tafsir tentang adanya keberkaitan antara peristiwa Tour De Java dengan Kunjungan Presiden Joko Widodo ke Hambalang juga diterima secara denotatif oleh ketiga informan melalui kalimat sarkas yang ditempelkan dalam kolase. 'Sidak ke Hambalang sedetik, rusak Tour De Java sebulan' dimaknai sebagai kalimat yang memiliki makna yang serupa dengan peribahasa 'karena nila setitik, rusak susu sebelanga'. Selain kalimat ini, ada pula kalimat sarkas yang ditempelkan di sebelah gambar rekaman layar situs berita. Adapun gambar tersebut memuat judul berita yang berbunyi 'SBY: Jangan Paksakan Bangun Infrastruktur Saat Ekonomi Sulit'. Kalimat sarkas yang disandingkan berbunyi 'Lagi kondisi ekonomi bagus aja pembangunan Hambalang seperti ini'. Kalimat-kalimat sarkas tersebut diterima sebagai sebuah keberkaitan antar peristiwa Tour De Java dan kunjungan presiden ke Hambalang. 
Menariknya informan Robi mulai bergeser dari transparant mode ke referential mode. Menurut Michelle, hal ini mungkin terjadi sebab audiens bisa berubah cara pandang tergantung pada semesta pengetahuan maupun pengalaman yang dimiliki (Michelle, 2007). Informan Robi menangkap bahwa gambar kolase ini menempatkan Susilo Bambang Yudhoyono dan Joko Widodo dalam posisi yang saling oposisi, seperti penjelasannya berikut:

"Saya tidak pro Jokowi, jadi kalau pun saya seolah-olah statement saya 'agak' ada kesan memilih Jokowi bukan karena Jokowi-nya sih, lebih karna sudah dibikin patah hati dengan SBY".

Informan Robi beranggapan bahwa jika dirinya menerima logika gambar kolase yang menyudutkan Susilo Bambang Yudhoyono, maka ia dianggap pendukung Joko Widodo. Informan Robi menolak dianggap pendukung Joko Widodo sebab ia memiliki pengalaman buruk pribadi. Ia mengatakan:

"Kembali lagi ke statement saya di awal, patah hati dengan SBY bagaimana SBY memimpin 10 tahun tapi sorry dalam 10 tahun itu tidak ada tindakan yang nyata tentang HTI misalnya FPI. Bagaimana temen-temen di GKI Yasmin di banyak sekali gereja itu dibikin terkatung-katung karena semata-mata SBY ingin gini aja. Nggak ada komitmen terhadap kelompok perbedaan. Dulu pernah saya 2009 sempet pro SBY".

Berbeda dengan Informan Robi, informan Erma sejak awal menggunakan referensi pengalamannya untuk memaknai gambar kolase. Informan Erma tidak sepenuhnya mengadopsi logika yang ditawarkan oleh gambar kolase. Menurutnya:

"Pada waktu 2009 saya aktif di Solo jelas pengalaman Jokowi di Solo sangat menginspirasi, proses kebijakan apapun kemudian menata tidak lesu dan sebagainya menjadi preferensi luar biasa dibanding saya partisan dan dibanding saya mendukung Jokowi”.

Ada sebagian dari gambar kolase tersebut yang menyajikan kebenaran, yaitu pada bagian gambar Presiden Jowo Widodo melakukan kunjungan ke Hambalang. Informan Erna menafsirkan gambar tersebut sebagai bukti keaktifan dari sosok Joko Widodo. Argumennya ini didukung oleh sebuah cerita dari pengalamannya dulu saat masih aktif menjadi anggota PDIP di Solo. Ia menjelaskan bahwa ketika masih menjabat di Solo, Joko Widodo seolah tidak kehabisan energi dalam menjalankan tugasnya. Dengan demikian, wajar saja jika ketika menjadi Presiden ia mengadakan kunjungan ke berbagai tempat, salah satunya Hambalang.

Dari argumentasi kedua informan di atas, dapat dipahami bahwa ada jarak (namun tidak saling terpisah) dalam relasi informan dengan gambar kolase sebagai teks yang dibahas dalam penelitian ini. Jarak yang tercipta antara informan dengan teks terefleksi dari keraguan informan terhadap logika yang ditawarkan oleh gambar kolase. Informan meragukan 
bahwa ada keberkaitan antara peristiwa Tour De Java dengan kunjungan presiden Joko Widodo ke Hambalang. Informan menafsirkan bahwa gambar kolase hanya merefleksikan kebenaran secara parsial, yaitu bahwa Presiden Joko Widodo melakukan kunjungan kerja ke Hambalang dan Susilo Bambang Yudhoyono melakukan Tour De Java.

Berbeda dengan keempat informan sebelumnya, informan Eka dan informan Heru beranggapan bahwa mereka sebagai viewer berada terpisah dengan teks (mediated mode). Informan Eka berargumen:

"Saya kira, kok kalo saya meme ini kan tadinya fungsinya memang sebagai hiburan namun sejak tahun 2016 beralih fungsi politik untuk mencoba shaping persepsi publik untuk tujuan politik. Salah satu meme ini untuk menghegemoni publik dan untuk mencitrakan bahwa kalo SBY hanya bisa bersenang-senang dan tidak menghasilkan apa-apa pun. Ada semacam perang simbol yang diciptakan di sini lewat meme itu".

Informan Eka menjelaskan bahwa gambar kolase sebagai sebuah humor di ranah internet ia menyebutnya sebagai meme sengaja diciptakan dan/atau diplintir untuk tujuan politis, yaitu menggiring pendapat publik. Dengan demikian, ia memaknai bahwa logika yang ditawarkan oleh gambar kolase ini sebagai sebuah pendapat yang sudah diformulasikan.

Sejalan dengan informan Eka, informan Heru juga menangkap bahwa ada proses produksi gambar kolase ini yang juga harus diperhatikan sebelum mulai memaknai sebuah teks pada level denotatif.

"Bisa jadi kemudian menjadi propagandanya Jokowi tapi bisa jadi awalnya spontanitas dari kreator-kreator itu yang suka main di medsos bisa jadi seperti itu, tapi bisa jadi kemudian terus memang karena menguntungkan Jokowi terus diviralkan menjadi sedemikian rupa".

Informan Heru menggarisbawahi tentang teknis produksi dan amplifikasi gambar kolase ini sebagai konten humor di internet. Informan Heru hanya dapat menafsirkan kemungkinan terkait proses produksi gambar kolase ini sebab pembuat gambar kolase ini anonim.

Informan Heru memiliki sebuah kecurigaan ketika menafsirkan gambar kolase. Menurutnya, ada permasalahan pada pembuat gambar kolase dan mekanisme peredarannya. Informan Heru beragumentasi bahwa kemungkinan di mana gambar kolase tersebut diproduksi oleh seorang pengguna internet. Menurutnya, gambar kolase ini lantas viral ketika ditemukan dan diunggah ulang oleh pengguna lain yang memiliki akun dengan engagement signifikan di media sosialnya. Hal ini ditambah pula ketika pengguna dengan engagement signifikan ini merupakan pendukung Jokowi, praktis konten ini viral.

Atas argumentasi yang mempertimbangkan proses pembuatan dan peredaran gambar kolase, baik informan Eka dan informan Heru tidak 
menganggap bahwa logika yang ditawarkan gambar kolase merupakan sebuah kebenaran. Dapat diargumentasikan bahwa informan Heru dan informan Eka tidak menafsirkan bahwa korelasi peristiwa kunjungan Presiden ke Hambalang dengan Tour De Java yang dilakukan oleh Susilo Bambang Yudhoyono merupakan sebuah kebenaran.

Beranjak pada tingkat konotatif, informan Yuska menafsirkan bahwa gambar viral merupakan bagian dari kegiatan manajemen citra, baik oleh Susilo Bambang Yudhoyono maupun Joko Widodo. Ia mengatakan:

"Saya melihat pencitraan awal sangat kuat pada zaman SBY, pemerintah dipilh yang gagah ganteng dan larinya ke ibuibu pilih yang gagah, ganteng, dan itu memang sangat kuat jadi kita yang waktu itu mengalami pemilihan ketiga sangat merasakan yang dialami SBY namun dalam perjalanannya menjadi hal yang menghantam balik SBY karena pencitraanpencitraan itu tidak sesuai, ganteng ternyata gembeng, gagah ternyata galau kemudian menjadi kontra. Yang dilakukan Jokowi memang pencitraan tapi dalam masa-masa perjalanan itu memang dilakukan sesuai dengan yang dicitrakan seperti kerja-kerja sangat kuat di satu sisi memang di kita ada yang kurang seperti beliau menghadapi kasus... kemudian sangat mengecewakan bagi kita tapi kita ga bisa menyalahkan walau tidak sempurna. Ini akan menjadi catatan kita bahwa pada masalah berikutnya pencitraan akan menjadi hal yang sudah biasa seperti itu".

Informan Yuska menangkap implikasi dari gambar kolase berupa sentimen negatif terhadap citra Susilo Bambang Yudhoyono. Menurutnya, citra yang terbangun di benak publik tentang
Susilo Bambang Yudhoyono terganggu karena ada refleksi ketidakkonsistenan sikap seperti yang ditampilkan dalam gambar kolase. Menurutnya, proyeksi citra Susilo Bambang Yudhoyono adalah sebagai sosok yang gagah namun galau. Informan Yuska juga sempat menyinggung kekurangan Presiden Joko Widodo dalam menjalankan tugasnya sebagai implikasi terhadap citranya. Informan Yuska memaknai citra Presiden Joko Widodo sebagai seorang pekerja.

Berbeda dengan informan Yuska, informan Robi menafsirkan bahwa tidak ada implikasi dari gambar kolase terkait citra masingmasing figur. Menurutnya, ia tidak menemukan bagian yang dalam gambar kolase yang dapat diidentifikasi berkaitan dengan manajemen citra Joko Widodo maupun Susilo Bambang Yudhoyono. Ia mengungkapkan:

"Karena Mas Yuska juga bilang ngganteng gagah tibake gembeng pandangan itu tidak salah, tapi pandangan itu tidak terbukti, tidak mempunyain fakta yang menunjukkan tiba-tiba popularitas SBY tiba-tiba menurun setelah tidak menjadi presiden karena kita tidak punya tools untuk menguji itu".

Dengan demikian, informan Robi secara konsisten mencari referensi dari sumber di luar gambar kolase untuk memulai tafsirnya. Jika argumentasi informan Robi disandingkan dengan argumentasi informan Yuska, maka dapat dipahami bahwa informan Yuska menentukan posisinya sebagai dominant/ 
preffered, sedangkan posisi yang ditentukan oleh informan Robi adalah negotiated. Posisi informan Yuska menerima logika gambar kolase bahwa secara denotatif ada korelasi antara peristiwa kunjungan kerja Presiden Joko Widodo ke Hambalang dengan peristiwa Tour De Java. Sedangkan secara konotatif, informan Yuska mengidentifikasi bahwa gambar kolase memiliki keberkaitan dengan manajemen citra masing-masing figur. Meskipun tanpa tambahan data yang valid dalam gambar kolase, informan Yuska menyepakati logika yang ditawarkan oleh gambar kolase. Sedangkan informan Robi terus menerus mencari referensi di luar gambar kolase. Kendati demikian, ia tidak sepenuhnya menolak logika yang ditawarkan oleh gambar kolase. Pengalaman pribadinya menjadi landasan untuk menerima sebagian logika yang ditawarkan oleh gambar kolase.

Tafsir yang berbeda ada pada informan Erma. Pada level denotatif, informan Erma berpegang pada pengalamannya ketika aktif menjadi anggota PDIP di Solo. Pada level konotatif pun ia hanya menafsir sentimen positif terhadap pemerintahan Joko Widodo dalam gambar kolase. Menurutnya:

"Kalau saya lihat di beberapa kementrian, reformasi untuk perubahan di kebijakan sudah wujud misal soal listrik, persoalan hukum dan HAM, tinggal ini kan warisan”.

Dapat diargumentasikan bahwa informan Erma menerima logika gambar kolase hanya di bagian bahwa Presiden Joko Widodo melakukan kunjungan kerja ke Hambalang. Ia menafsir peristiwa tersebut sebagai salah satu kebiasaan Joko Widodo yang dianggapnya sebagai sosok yang giat dan banyak melakukan perubahan. Informan Erma membangun tafsirnya berdasarkan cerita-cerita yang berkembang dalam lingkungannya sebagai partisan PDIP.

Sejalan dengan informan Erma, informan Habsari juga mengungkapkan bahwa statusnya yang merupakan partisan PDIP membentuk tafsir level konotatif yang ia miliki atas gambar kolase. Informan Habsari mengungkapkan:

"Jelas kalau saya ditanya sebagai PDI, PDI partai oplosan. Jokowi bukan dari PDI maka jelas akan beda seperti kalau kita Jokowi dari PDI".

Sama seperti informan Erma, informan Habsari juga selalu mencari referensi dari luar teks. Selain itu, informan Habsari juga hanya fokus pada bagian gambar kolase yang memuat tentang Joko Widodo.

Posisi informan Erma dan informan Habsari yaitu negotiated. Tafsir mereka berdua terhadap gambar kolase pada level denotatif hingga level kontotatif selalu dibangun dari pengalaman atau pengetahuan yang didapat dalam lingkarannya. Ketika tidak ada pengalaman maupun bekal pengetahuan yang bisa dijadikan landasan menafsir, maka mereka memilih untuk tidak menerimanya. Alih-alih menyangkal logika 
yang ditawarkan gambar kolase, mereka berusaha mencari informasi lain untuk dapat menafsir.

Di sisi lain, informan Eka dan informan Heru menganggap bahwa viewer dan teks terpisah satu sama lain. Jika pada level denotatif mereka menekankan adanya proses produksi meme, maka pada level konotatif mereka mengungkapkan tafsir mereka atas motivasi dibuatnya gambar kolase. Informan Heru mengatakan:

"Untuk sementara penangkal medsos yang nggak karu-karuan kayak gini, Jokowi kan selain pendekatan kulturalisme yang disampaikan Yuska untuk mencegah isuisu SARA secara sebenarnya kan sudah ditingkatan konstitusi sudah digodok juga kan kominfo membatasi tentang meme termasuk MUI pun mau mengharamkan itu".

Menurut informan Eka, media sosial tengah dieksploitasi untuk kepentingan tertentu. Konten menjadi salah satu produk eksploitasi, termasuk juga gambar-gambar kolase yang banyak beredar di internet. Ia menafsir bahwa dalam situasi yang demikian viewer perlu mengambil jarak dari teks, harapannya agar dapat melihat kebenaran yang tidak disetir oleh kelompok tertentu.

Sejalan dengan hal tersebut, informan Eka juga mengungkapkan kegelisahannya tentang konten-konten dalam media sosial yang digunakan untuk kepentingan politik. bahwa ada motivasi terselubung dibalik gambar kolase dan ada kemungkinan publik tidak dapat mengidentifikasinya dengan mudah. Ia sependapat dengan informan Heru dengan mengatakan:

"Nah itu betul, dan bisa ditelan begitu saja".

Kendati khawatir dengan adanya motivasi selain candaan dibalik gambar kolase, informan Eka beranggapan konten internet seperti gambar kolase (berformat visual) tidak memiliki dampak yang signifikan dibanding konten yang berbentuk verbal.

Menariknya, baik informan Heru maupun informan Eka tidak menolak sepenuhnya logika yang ditawarkan oleh gambar kolase di bagian tertentu. Meski mereka mencurigai adanya motif penggiringan opini dibalik pembuatan gambar kolase, keduanya juga menerima logika bahwa ada sentimen positif terkait citra Jokowi dengan peristiwa kunjungannya ke Hambalang. Argumen ini dilandaskan oleh pernyataan keduanya yang menceritakan kembali pengalamannya memilih Joko Widodo pada pemilu presiden lalu. Informan Heru menceritakan:

"Kalau sikap saya gini, saya aktivis 98 waktu itu berlawanan dengan orde baru jelas, orde baru salah satu elemen penting orde baru militer, tentara. Ketika saya sebut militer maka sudah ada garis yang sangat jelas, militer harus seperti itu. Sama saja dengan sikap saya mendukung Jokowi”. 
Sedangkan informan Eka lebih menunjukan harapan bahwa Presiden Joko Widodo memenuhi janji kampanyenya:

"Kalau saya bukan soal memaklumi, tetapi masih ada ruang untuk potensi untuk menagih janji masih ada".

Dalam pemahaman mereka, peristiwa kunjungan Presiden Joko Widodo ke Hambalang merupakan itikad baik untuk menyelesaikan sebuah masalah, meskipun solusinya belum diketahui. Temuan ini menjelaskan bahwa informan Eka dan informan Heru berada pada posisi negotiated.

Informan Yuska memaknai bahwa citra Susilo Bambang Yudhoyono bersentimen negatif dan citra Presiden Joko Widodo bersentimen positif. Sentimen positif yang dimaknai informan Yuska sebagai citra Presiden Joko Widodo didapat dari pemahaman atas logika gambar kolase. Menurut informan Yuska, Presiden Joko Widodo tampil sebagai pekerja yang merespons kegagalan proyek Hambalang di masa Susilo Bambang Yudhoyono. Citra Susilo Bambang Yudhoyono dimaknai sebaliknya, yaitu sebagai oposisi Joko Widodo dalam kasus Hambalang. Menurut informan Yuska, ada citra keperkasaan yang nampak dari fisik Susilo Bambang Yudhoyono. Namun, ini tidak berimbang dengan kegagalannya dalam kasus Hambalang.

Pengalaman mengenyam pendidikan berkontribusi terhadap sudut pandang informan Yuska dalam melihat gambar kolase yang ditampilkan. Informan Yuska tidak mengkritisi gambar kolase yang ditampilkan padanya sebagai sebuah teks. Ia menerima teks sebagai sebuah cerminan realitas, bukan sebuah produk yang dihasilkan oleh pihak tertentu. Sudut pandang informan Yuska menjadi berbeda dengan informan lainnya yang mengenyam pendidikan hingga sarjana dan magister. Ada nalar kritis dari informan lainnya yang digunakan untuk memahami gambar kolase. Kemampuan informan Yuska untuk menerima gambar kolase sebagai realita dapat dilihat dari konteks yang lebih luas lagi, yaitu sistem pendidikan sekolah menengah atas.

Selain itu, pekerjaan informan Yuska dan keterlibatannya di Lintas Iman dan HAM membuatnya akrab dengan informasi-informasi kejadian tentang dunia politik. Latar belakang ini menjadikan informan Yuska akrab dengan diskursus politik yang berkembang di Indonesia. Ia dengan mudah memahami konstelasi kejadian yang ada selama pemerintahan Susilo Bambang Yudhoyono dan selama pemerintahan Joko Widodo. Keakraban informan Yuska dengan diskursus politik di Indonesia ini juga membuatnya mudah menangkap pesan dari gambar kolase tentang kunjungan Presiden Joko Widodo ke Hambalang. Kendati akrab dengan informasi tentang kondisi politik di 
Indonesia, sumber informasi tersebut adalah sekunder. Informan Yuska tidak berada dalam lingkaran yang sama dengan kedua tokoh politik. Ia mendapatkan informasi melalui konsumsi media dan perbincangan dengan rekan-rekannya. Kondisi ini menjadikan Yuska mengetahui berita tentang kunjungan Susilo Bambang Yudhoyono ke Hambalang.

Proses encoding-decoding bisa terjadi di kalangan audiens media yang interaktif seperti internet (Shaw, 2017). Dalam proses ini, informan Yuska telah terpengaruh dengan argumen yang dibawa oleh gambar viral. Informan Yuska menerima logika dari gambar viral karena ia memiliki referensi yang sama. Opini yang dimiliki oleh informan Yuska sudah terarahkan seperti opini yang dimiliki oleh pembuat gambar viral tersebut sekaligus dengan penyebarnya juga.

Informan Robi memahami teks menggunakan pengalamannya sebagai keturunan Cina yang hidup di Indonesia. Ia menangkap adanya sentimen negatif terhadap citra Susilo Bambang Yudhoyono dan sentimen positif terhadap citra Joko Widodo. Kendati demikian, referensi pengalamannya justru membantunya untuk menegosiasi teks. Baginya sentimen negatif dan positif terkait citra masing-masing tokoh dalam gambar kolase tidak bisa langsung diterima. Ia merujuk pada pengalamannya sebagai warga keturunan Cina yang tidak mendapat perlindungan baik dalam masa pemerintahan Susilo Bambang Yudhoyono maupun masa pemerintahan Presiden Joko Widodo. Informan Robi menyebutkan peristiwa di GKI Yasmin sebagai contohnya. Menurutnya, baik Susilo Bambang Yudhoyono dan Joko Widodo sama-sama pihak yang diam saja terkait masalah rasisme di Indonesia.

Tafsir dari informan Robi bisa dipahami dari segi empiris. Sejak masa orde baru, warga negara Indonesia yang berketurunan Tionghoa seperti tidak mendapat tempat di negara ini. Setijadi mencatat bahwa selama masa Orde Baru, keberadaan warga negara Indonesia berketurunan Tionghoa seolah dihapus atau setidaknya disembunyikan dari publik (Setijadi, 2016). Baru kemudian ketika Abdurrahman Wahid menjabat sebagai Presiden Republik Indonesia ke-4 terjadi penghapusan diskriminasi terhadap kelompok Tionghoa Indonesia (Dawis, 2013). Namun, ini bukan berarti tidak ada lagi kejadian diskriminatif yang menimpa kaum Tionghoa Indonesia. Peristiwa yang menyeret Basuki Tjahaja Purnama ke penjara merupakan bukti bahwa masih ada perlakuan diskriminatif kepada kelompok ini (Pratiwi, 2017).

Informan Erna memaknai citra Presiden Joko Widodo sebagai sosok yang pekerja keras. Tafsirnya diperoleh dari pengalamannya sebagai simpatisan PDIP. Dengan kata lain, informan Erna bergabung dengan partai 
politik yang sama dengan tempat Presiden Joko Widodo bernaung. Secara sederhana, informan Erna memiliki pandangan politik yang sejalan dengan Presiden Joko Widodo. Pandangan politiknya ini lantas membantunya dalam mempersepsi kegiatan kunjungan ke Hambalang yang dilakukan oleh Presiden Joko Widodo. Kendati demikian informan Erna tidak menangkap sentimen negatif atas citra Susilo Bambang Yudhoyono.

Emosi partisan sangat berkaitan dengan kondisi eksistensi partai. Partisan dapat memunculkan emosi seperti amarah maupun bahagia ketika terjadi sesuatu dengan partainya. Partisan bisa merasakan emosi yang kuat ketika eksistensi partainya terancam karena kalah dalam pemilu, namun merasa lebih positif ketika partainya menang (Huddy, Mason, \& Aarøe, 2015). Seperti yang dialami oleh informan Erna, ketika ia mendapati konten media yang secara positif menggambarkan Joko Widodo, maka ia akan menyetujuinya.

Meskipun informan Erna tidak pernah bekerja dengan Joko Widodo secara langsung, konten media menjadi sumber informasi baginya untuk menangkap proyeksi citra Joko Widodo dalam benaknya. Politikus memang melakukan manajemen citra terhadap kontennya di media sosial, termasuk pula dengan Joko Widodo (Nugraha, 2018). Namun, citra yang ditangkap oleh publik seringkali berbeda dengan yang disampaikan oleh orang-orang di belakang tim manajemen citra. Adanya upaya untuk mengelola citra ini akan berdampak pada impresi yang dimiliki oleh publik terhadap politikus tertentu (Lalancette \& Raynauld, 2019). Ketika informan Erna tidak pernah terpapar dengan konten-konten yang berkaitan dengan Susilo Bambang Yudhoyono, maka ia menjadi kesulitan menciptakan impresi terhadap politikus tersebut.

Informan Erna tidak memiliki pengalaman berada dalam satu institusi bersama dengan Susilo Bambang Yudhoyono. Ia tidak memiliki pengetahuan yang dapat dijadikan landasan untuk menafsir citra Susilo Bambang Yudhoyono. Logika yang dipaparkan oleh gambar kolase pun tidak dianggap cukup membantunya. Perbedaan latar belakang pengetahuan dan pengalaman yang dimiliki informan Erna berbeda dengan pembuat gambar viral. Ini membuat informan Erna tidak menangkap citra dari Susilo Bambang Yudhoyono yang berusaha diproyeksikan oleh pembuat gambar.

Seperti yang dilakukan oleh informan Erna, informan Habsari pun hanya merujuk pada pengalamannya sebagai partisipan PDIP. Perbedaannya hanya informan Habsari sempat menerima logika yang ditawarkan teks. Namun, karena dianggap tidak cukup memberikan informasi, informan Habsari lantas merujuk 
pada pengalaman pribadinya sebagai partisan PDIP. Atas dasar kesamaan institusi, informan Habsari melihat bahwa semua kegiatan yang dilakukan Presiden Joko Widodo adalah hal yang patut.

Informan Eka sejak awal mencurigai proses dibalik pembuatan gambar kolase sebab menurutnya ada tujuan tertentu dibaliknya. Menurutnya gambar kolase ini merupakan produk yang dihasilkan oleh salah satu pendukung Presiden Joko Widodo atau pendukung Susilo Bambang Yudhoyono. Logika ini pula yang menuntun informan Eka untuk mencurigai bahwa citra yang berusaha ditampilkan kedua tokoh tersebut merupakan fabrikasi belaka.

Dalam proses fabrikasi ini, informan Eka berpendapat bahwa masyarakat dapat dibentuk persepsinya melalui konten-konten di internet. Ini karena ia beranggapan bahwa masyarakat masih bisa dihegemoni menggunakan kekuatan media. Oleh karena itu, informan Eka secara hati-hati mengecek terlebih dahulu logika yang ditawarkan gambar kolase sebelum mulai menerimanya sebagai sebuah kebenaran. Proses mengetahui produksi teks ini penting baginya, meskipun teks yang dimaksud hanyalah humor yang tersebar di internet. Posisi informan Eka secara konsisten menegosiasi teks yang dimaknainya karena adanya nalar kritis yang didapat dari pengalamannya bersekolah magister hingga menjadi Panwas Kabupaten/ Kota di wilayah Jawa Timur.

Kecurigaan informan Eka tentang adanya tujuan tertentu dalam sebuah konten di internet ini seperti yang digagas oleh Huntington dkk. Menurut Huntington dkk., sebuah konten humor seperti meme, berusaha menyampaikan sebuah argumen tertentu (Huntington et al., 2017). Menurutnya, ketika audiens memiliki kecocokan ideologi dengan argumen yang berusaha disampaikan oleh konten humor tersebut, maka audiens akan lebih setuju dibanding mereka yang menganut ideologi berbeda. Informan Eka telah memahami bahwa mekanisme yang demikian terjadi dibalik pembuatan gambar viral yang dibahas dalam penelitian ini. Oleh karena itu ia mengira bahwa pendukung Joko Widodo ada dibalik pembuatan gambar viral.

Adanya proses pembuatan gambar viral sebagai konten humor internet menandakan bahwa ada perubahaan cara berkomunikasi tentang isu politik di internet. Yang \& Jiang menemukan bahwa menyebarkan konten satir politik dalam internet merupakan sebuah ritual (Yang \& Jiang, 2015). Hal ini sejalan dengan yang diungkapkan oleh Fang, bahwa tujuan pembuat dan penyebar konten humor seperti meme politik adalah sebagai ritual di antara kelompoknya (Fang, 2018). Selain itu, tujuan lain dari pembuatan dan penyebaran konten 
humor politik di internet adalah sebagai bentuk kritik dan senang-senang belaka.

Sama halnya dengan informan Eka, informan Heru pun sejak awal bahwa gambar kolase telah melalui proses produksi yang tidak lepas dari tujuan politis. Informan Heru menekankan bahwa ada aktor-aktor yang terlibat dalam proses produksi gambar kolase. Menurutnya, aktor-aktor inilah yang dianggap mendiseminasikan pemikirannya baik secara spontan maupun terencana. Informan Heru beranggapan bahwa orang-orang yang beropini mirip dengan argumen yang disampaikan oleh gambar viral adalah orang-orang yang sudah terpengaruhi.

Aktor memang dapat menjadi seorang opinion leader yang pendapatnya mampu membentuk pendapat publik. Kemampuan persuasif aktor menjadi lebih kompleks lagi dengan bantuan teknologi komunikasi. Dalam internet, aktor dapat memanfaatkan konten untuk diviralkan agar opininya mampu memengaruhi banyak orang. Seperti kasus ekspos 29 kasus korupsi di Sina Weibo (situs blog di negara China) yang dibocorkan oleh pengguna situs Sina Weibo tersebut (Nip \& Fu, 2016). Pada dasarnya pengguna internet hanya orang biasa, namun ketika ia memanfaatkan karakteristik media sosial yang populer, ia dapat menjadi opinion leader (Weeks, ArdèvolAbreu, \& De Zúñiga, 2017). Posisinya ini pula semakin diperkuat dengan popularitas sosial media dimata media massa dengan demikian aplifikasi isu menjadi lebih besar. Sama halnya dengan yang dimaksudkan oleh informan Heru, menurutnya konten humor tentang Susilo Bambang Yudhoyono dan Joko Widodo tidak akan memiliki kekuatan jika tidak disebarkan oleh opinion leader melalui media sosial dan diamplifikasi oleh media massa.

Meskipun sumber gambar viral yang ada dalam penelitian ini anonim, informan Heru tetap beranggapan bahwa gambar ini berusaha menggiring opini publik. Hal ini sesuai dengan yang diungkapkan oleh Hampton, Shin, \& $\mathrm{Lu}$ bahwa meskipun pembuat konten bisa anonim, namun ketika diunggah ke media sosial praktis akan terlacak pengguna mana yang melakukan unggahan (Hampton, Shin, \& Lu, 2017). Menariknya, pengguna cenderung mudah terpengaruh dengan konten politik yang diunggah oleh pengguna lain yang termasuk teman (Anspach, 2017).

\section{SIMPULAN}

Dari pemaparan hasil penerimaan informan terkait meme Hambalang dihasilkan bahwa ada pemaknaan yang beragam yang dimiliki oleh informan mengenai munculnya satir tentang Hambalang. Informan memaknai bahwa satir tersebut menunjukkan cerminan realita (text as life) bahwa disejajarkannya foto SBY dan 
Jokowi dalam satir sebagai bentuk rivalitas keduanya. Di sisi lain, kemunculan satir tersebut dimaknai sebagai humor dalam ranah internet, sekaligus satir tersebut sebagai eksploitasi media sosial untuk kepentingan tersebut.

Posisi penerimaan mengenai citra politik SBY dan Jokowi pada satir Hambalang berada pada posisi contesting reading. Ini berarti satir tersebut mencitrakan Jokowi kepada citra positif namun tidak secara langsung mengarah pada citra negatif Susilo Bambang Yudhoyono. Citra Jokowi yang bekerja dan Susilo Bambang Yudhoyono pada kegagalan pemerintahan membangun Hambalang. Posisi negotiated pada pemaknaan terkait citra tersebut dilatarbelakangi adanya frame of reference dan field of experience informan yang berbeda diantaranya preferensi partai, aktivitas politik dan informasi media yang diterima informan yang membuat informan tidak begitu saja mempercayai gambar yang diproduksi satir tersebut. Kehadiran Jokowi ke Hambalang juga dianggap bukan semata-mata aksi "balas dendam" akan pidato SBY, namun aksi kerja nyata Jokowi.

Terdapat informan yang berada pada posisi hegemonic reading. Ia memaknai bahwa Joko Widodo tampil sebagai pekerja yang merespons kegagalan proyek Hambalang di masa Susilo Bambang Yudhoyono. Selain itu ada citra keperkasaan yang nampak dari fisik
Susilo Bambang Yudhoyono. Namun, ini tidak berimbang dengan kegagalannya dalam kasus Hambalang.

\section{DAFTAR PUSTAKA}

Anspach, N. M. (2017). The new personal influence: how our Facebook friends influence the news we read. Political Communication, 34(4), 590-606. https:// doi.org/10.1080/10584609.2017.1316329.

Dawis, A. (2013). Orang Indonesia Tionghoa mencari identitas. Retrieved from https:// books.google.co.id/books/about/ORANG INDONESIA_TIONGHOA_Mencari Identit.html?id=SIVJDwAAQBAJ\&redir_ $\mathrm{esc}=\mathrm{y}$.

Fang, K. (2018). Turning a communist party leader into an internet meme: the political and apolitical aspects of China's toad worship culture. Information Communication and Society, 1-21. https:// doi.org/10.1080/1369118X.2018.1485722.

Firmansyah, P. (2008). Marketing politik antara pemahaman dan realitas. Jakarta: Yayasan Obor Indonesia.

Hampton, K. N., Shin, I., \& Lu, W. (2017). Social media and political discussion: when online presence silences offline conversation. Information Communication and Society, 20(7), 1090-1107. https://doi. org/10.1080/1369118X.2016.1218526.

Huddy, L., Mason, L., \& Aarøe, L. (2015). Expressive partisanship: campaign involvement, political emotion, and partisan identity. American Political Science Review, 109(1), 1-17. https://doi. org/10.1017/S0003055414000604.

Huntington, H. E., Rosa, A., Martey, M., Anderson, A. A., Burgchardt, C. R., 
Long, M., \& Mcivor, D. W. (2017). The affect and effect of internet memes: Assessing perceptions and influence of online user-generated political discourse as media. $\mathrm{PhD}$ dissertation, Colorado State University, USA. Retrieved from https://mountainscholar.org/ handle/10217/183936.

Jenkins, H. (2004). The cultural logic of media convergence. International Journal of Cultural Studies, 7(1), 33-43. https://doi. org/10.1177/1367877904040603.

Lalancette, M. \& Raynauld, V. (2019). The power of political image: Justin Trudeau, Instagram, and celebrity politics. American Behavioral Scientist, 63(7), 888-924. Retrieve from https://doi. org/10.1177/0002764217744838.

McQuail, D. (2010). Mass communication theory. London: Sage Publications.

Michelle, C. (2007). Modes of reception: A consolidated analytical framework.

Communication Review, 10(3), 181-222. https://doi. org/10.1080/10714420701528057.

Nip, J. Y. M. \& Fu, K. W. (2016). Challenging official propaganda? public opinion leaders on Sina Weibo. China Quarterly, 225, 122 144. Retrieve from https://doi.org/10.1017/ S0305741015001654.

Nugraha, A. W. (2018). The role of social media in enhancing personal political brand a study in president of republic of Indonesia, President Joko Widodo. Indo IGCC Proceeding, 2, 431-435. https://doi.
org/10.7454/IGCC.V2I0.129.

Pratiwi, P. S. (2017). Ahok divonis dua tahun penjara. Retrieved October 2, 2019, from https://www.cnnindonesia.com/ nasional/20170509080949-12-213328/ ahok-divonis-dua-tahun-penjara.

Setijadi, C. (2016). Ethnic Chinese in contemporary Indonesia: changing identity politics and the paradox of sinification. Perspective, (12)1-11. Retrieve from https://pdfs.semanticscholar. org/c3 dc/8fb032f649878348ec34563 18a90e6840ff8.pdf.

Shaw, A. (2017). Encoding and decoding affordances: Stuart Hall and interactive media technologies. Media, Culture and Society, 39(4), 592-602. https://doi. org/10.1177/0163443717692741.

Weeks, B. E., Ardèvol-Abreu, A., \& De Zúñiga, H. G. (2017). Online influence? social media use, opinion leadership, and political persuasion. International Journal of Public Opinion Research, 29(2), 214-239. https:// doi.org/10.1093/ijpor/edv050.

Wibowo, K. A. \& Mirawati, I. (2013). Realitas politik Indonesia dalam "kacamata" pengguna Twitter. Jurnal Kajian Komunikasi, 1(1), 11. Retrieve from https:// doi.org/10.24198/jkk.v1i1.6027.

Yang, G. \& Jiang, M. (2015). The networked practice of online political satire in China: Between ritual and resistance. International Communication Gazette, 77(3), 215-231. Retrieve From https://doi. org/10.1177/1748048514568757. 